\title{
The Theory and Practice of Confucian Value of Integrity: The Brunei Case Study
}

\author{
Patrick Kim Cheng Low ${ }^{1} \&$ Sik Liong Ang ${ }^{2}$ \\ ${ }^{1}$ University of South Australia, Adelaide, South Australia \\ ${ }^{2}$ Faculty of Business, Economics and Policy Studies, Universiti Brunei Darussalam, Gadong BE, Brunei \\ Correspondence: Sik Liong Ang, Faculty of Business, Economics and Policy Studies, Universiti Brunei \\ Darussalam, Jalan Tungku Link, Gadong BE 1410, Brunei. E-mail: angsikliong@gmail.com
}

Received: March 11, 2012 Accepted: May 9, 2012 Online Published: July 16, 2012

doi:10.5539/ijbm.v7n14p114 URL: http://dx.doi.org/10.5539/ijbm.v7n14p114

\begin{abstract}
Kothari (2010) speaks of executive greed, and here, the practitioners/academicians examine those leaders/managers who embrace and practice the value of integrity from the Confucian perspective in South East Asia, more so, in the Brunei context. With inputs and feedback from various respondents and with the use of Chinese sayings and proverbs, the authors present and interpret the Confucian value of integrity. From Confucius comes the emphasis on leadership with integrity which is identified with positive, harmonious relationships as well as the values of benevolence and reciprocity that bring many benefits to business prosperity. The practice of Confucian teachings can bring much peace, learning, and growth for business sustainability.
\end{abstract}

Keywords: leaders, integrity, confucian, rén (仁, benevolence), kindness, humaneness

\section{Introduction}

Kothari (2010: Preface) highlighted that Americans were infuriated by the news of executive bonuses in the companies that were being bailed out by the government. Without the billions in governmental support and help, most of these businesses would not have continued to exist. Although "many managers of these firms were responsible for their firms' financial decline, they were rewarding themselves as if they deserved high compensations for their disastrous business decisions, policies, and actions". The financial excesses brought these executives worldwide notoriety and public ridicule.

The authors feel that the highly publicized cases are only the few drops in the vast pool of executive greed. There are thousands of executives earning high compensations unjustifiably in countless big companies. The reported incidents shed light on how corporate leaders in the United States and elsewhere have been enriching themselves, legally or unlawfully, at the expense of consumers, employees, distributors, suppliers, stockholders, and the society at large.

Indeed, without integrity at the top as well as the bottom of a company as a whole, a business is usually short-lived and it cannot survive in the long term. In fact, when business integrity is present throughout the deepest layers of a company and not just at its surface, it becomes the core, the heart and soul of the company's culture; and this can mean the difference between a company that succeeds and a company that fails.

The aim and objectives of the paper are to examine the various ways in which leaders should be of high integrity, and they are seen from the Confucian perspective; and it is intended to examine or highlight several key concepts of Confucian leadership, one of which is being a leader of high integrity and applying reciprocity to promote positive and good relationships among followers or each other in a society. The practitioner-cum- researchers examine upright leaders, looking from the Confucian angle in South East Asia, more so, in the Bruneian context - after all, the interviews and samples are taken from Chinese in Brunei.

\section{Literature Review}

In essence, the authors hold the view that Confucian value of integrity is very much tied-in with the spiritual essence of Confucianism, and leaders have to live and lead right, and go by the way of the Tao. If one does not live right, one cannot lead right. And the explanations are as follows: 


\subsection{What Confucius Means by Dao?}

Tao can be roughly translated into English as "the path", or "the way", referring to a power which envelops, surrounds and flows through all things, living and non-living. Tao is the Oneness of everything. [The Tao is seen as less emphasized in Confucian teachings, and its practical aspects have been stressed.] (Low, 2011). Another Chinese character (德, dé) means good virtues. These two Chinese characters 道 德 (Dào dé) when used together are important because Confucius encouraged his students to live by the principles of setting one's aspirations on the way of life (道, Dào), embraces and practices on good virtues (德, dé). To attain a peaceful and harmonious relationship in life, an individual also needs to rely on one's (仁, rén) humaneness, and relax in the study of the arts. (Analects of Confucius, Chapter VII: 6). The eight good virtues Confucian scholars commonly propounded are as follows:- 1) Filial piety (孝, xiào);2) brotherhood, peer-ship and equality (悌, ti); 3) loyalty and fidelity (忠, zhōng);4) trustworthiness (信, xìn); 5) courtesy and politeness (禮, lǐ ); 6) righteousness, right conduct and courage (義, yi); 7) upright, honourable, integrity and character (廉, lian ), and 8) humility and shamefulness (恥, chı ).

\subsection{What is the Confucian Value of Integrity (廉, hanyu pinyin lian)?}

Integrity comes from the same Latin root as "integer", literally means "whole": As one remembers numbers such as integers from mathematics - they are whole numbers. Integrity truly means whole, or complete. Therefore, in this context, integrity is the inner sense of "wholeness", deriving from qualities such as honesty, sincerity and consistency of character. Integrity refers to the quality of a person's character.

Integrity is also assigned to various aspects or elements of a person's life. One speaks of attributes such as professional, intellectual and artistic integrity. However, the most philosophically important sense of the term 'integrity' refers to the general character. Philosophers have been particularly concerned to understand what it is for a person to exhibit integrity throughout his or her life. (SEP, 2011). As such, one may judge that others 'have integrity' to the extent that they act according to the core values, beliefs and principles they claim to hold. Integrity is a concept of consistency of actions, values, methods, measures, principles, expectations, and outcomes. In ethics, integrity is considered as the honesty and truthfulness or accuracy of one's actions. Integrity can be considered as the reverse or opposite of hypocrisy, in that it considers internal consistency as a virtue, and suggests that parties holding apparently conflicting values should account for the discrepancy or alter their beliefs.

\subsection{Being an Individual with the Confucian Value of Integrity (廉, Hanyu Pinyin lian)}

Confucius remarked, "Man's existence lies in his integrity. A man without integrity can exist merely through his luck." (Analects of Confucius, VI: 19). A person's integrity of being truthful and sincere to oneself and society is of great importance and it appears that many often overlooked that the essence of Confucianism is the "idea of being true to oneself in this world" (interestingly, there is an intrinsic or inside-out approach) when fulfilling obligations to family and others in society (Wang, 2004: 51). Here, we can cite - though non-Confucian, the Dalai Lama, who is true to himself or more so, the Universe (Universal 'self'), and, in a way, be seen as an individual with the Confucian value of integrity.

When one is truthful to oneself, one would then be able to fulfill one's obligation to look after one's family in a caring and sincere way. When an individual can achieve this, then for one to care and contribute to one's society would come in a natural way. Thus, integrity is in direct opposite to being greedy or selfish. The sincerity and integrity of an individual can also be said to be the key strengths of the Confucian ethics when applied to the social relationship in society (Low \& Ang, 2011, Low, 2010; Low, 2008). Whatever, even very little that each of us, individuals can do for our respective universe that would be great. After all, it would contribute to the overall goodness, similar to what the late Indian nationalist leader Mohandas Gandhi $(1869$ - 1948) said, that is, "be the change you want to see in the world." And individuals do make a difference in ethical actions. Being a sincere and reliable person, one can work confidently in partnerships with others such as the family, the government, the political parties and the civil society to safe guard and advance the future of a society with corporate social responsibility. And more importantly, an element of long-termism prevails (Low, 2010a).

\subsection{Leading with the Confucian Value of Integrity (廉, Hanyu Pinyin lian)}

Leading with integrity is one of the great challenges of leadership. Leadership phrases such as "walking the talk" and "leading by example" are common remarks made by employers and employees. Unfortunately, an individual can not just lead by power, force or authority alone. (S)he really has to "do the right thing, even if nobody is watching", as the saying goes.

Integrity is really tested when difficulties and hardships come into one's leadership. Take for example, when the 
majority of the followers do not understand or find it difficult to understand what the leader is trying to convey or lead, the leader needs to pause, reflect and review how (s)he can make his or her followers understand his or her purpose of doing/leading. True integrity does not take the easy way out for not making one's leadership transparent, open and accountable.

\subsection{Being a Good Corporate Person, the Confucian Perspective}

At its core, integrity begins with a corporate leader who understands the qualities of integrity which then filters down throughout the company into every department and every member's approach and attitude. A good corporate person does not do self-interested actions and engage in office politics for material gains, these are actions of a petty or small person (小人, xiao ren). A corporate person of high integrity will do various actions for the benefits of others - and the organization as a whole.

\section{Research Model}

Adopting a humanist (ren) approach, Confucians strive for the virtues of integrity and character (lian); human-orientated; they are concerned with their people. The researchers develop the following research model on Confucian leaders and their being caring.

Table 1 shows the research model: The Confucian Value of Integrity developed in this study.

Table 1 . The confucian value of integrity

"Being true to oneself in this world"
The opposite of hypocrisy
The opposite of greedy or being selfish.
Long-termism exists




\section{Research Methodology}

The research study was carried out with a total of eighty-three Chinese employers and employees from Small and Medium Enterprises (SMEs) in Brunei, and the period of study was from 16 March 2011 to 31 November 2011. Referring to many business researchers, sample sizes larger than 30 and smaller than 500 are appropriate for most research. Qualitative studies typically use small sample sizes because of the intensive nature of such studies (Cavana et al, 2001: 279; Sekaran, 2000: 296 - 7 and Roscoe, 1975). The sample size of eighty-three was used because of various aspects including costs, time accessibility and limited personal resources. The critical rationale behind choosing Chinese Bruneians as the key sample for this research is primarily because many studies have shown that Overseas Chinese including Chinese Bruneians are motivated and influenced by Confucian values (de Bary, Chan and Watson, 1960; Lien Kraar, 1994: 57; Low, 2009, 2006, 2002; Low and Ang, 2011d; Ang and Low, 2012), and hence the respondents' information and insights can be usefully harnessed, confirming and casting interesting light on leadership with high integrity as well as good ethical practices.

This research is based on a series of interviews - each time approximately 45 minutes though a few interviews stretched to an hour plus - conducted The study relies on the qualitative research method. It is worthy to note that similar to Low's $(2006,2006 \mathrm{a})$ studies, being assured of confidentiality and anonymity, the interviewees expressed themselves freely. At the beginning of these interviews, the researchers started with some small talk to put the interviewees at ease. Very often, a light conversation on their personal likes and interests, detected in previous interactions or previous telephone calls, would serve as a springboard for further discussions on the motivational sources of the interviewees. At times, the interviewers indirectly started off with or directly brought up Confucian quotations or anecdotes to serve as a discussion aid during the interviews. This interview method is helpful since it enables much qualitative data to be collected from the interviewees. To get more information and data from the various interviewees, open questions were deployed (Cavana, Delahaye and Sekaran, 2001); they were crafted as follows:

1) What are your views on being a leader with high integrity, the Confucian way?

2) Do you think that embracing and practicing 'The value of integrity' helps you to lead well in your line of business?

3) For what reasons do you need to be a leader with integrity?

4) What are the ways in which you are motivated by a leader who are concerned with integrity?

5) What do you like about being leader with integrity in the eyes of the employees, the Confucian 'style'?

6) What makes such an upright leader appealing or attractive?

Pilot-testing was felt necessary, as it was not easy to predict how respondents would interpret and react to the questions (Gill and Johnson, 1997). Checking was also done during the pilot testing to ensure that all the questions were understandable (Haworth (ed.), 1996: 47). They were also asked to suggest additional questions and to identify any highly relevant questions. To increase comprehension and improve clarity, this list of questions was then modified based on several respondents' feedback; for example, the above Question 5 was modified from "What do you like about being a leader with integrity in the eyes of the employees?" Interestingly, these questions also allowed the researchers to gather more information on the various sources of motivation from the interviewees. In this way, the authors attempt to find out and understand the interviewees' perceived values of being "a leader with integrity" and what makes the (Confucian) leader attractive.

To explain further, it is worthy to note that the researchers conducted this 45 minute-long (at least and at times stretched to an hour plus) in-depth interviews with each of them. They attempted to formalize-regularize the process as much as they could. However, they knew before they started that the more they would attempt to control the process, the less real wisdom they would get from the discussions. So the tension between doing "legitimate" (formal) qualitative research and getting the deepest possible responses from their interviewees became one the most interesting challenges that they confronted. Admittedly, the researchers at times strayed from the format; they then asked probing questions in the interviews where formal methods for generating data collection could easily be sacrificed in response to the richness and spontaneity of the intimate, unhurried conversational inquiry that permitted further checks or probes for additional clarification, examples, and so on.

An example of an inquiring, probing question posed is that of: "Why do you view that your followers are motivated when they know that you are an upright leader?", after the interviewees were answering this question: "What do you like about being seen as a leader with integrity?" 


\section{Findings}

Seventy-nine interviewees or 95.1 percent of the total number of interviewees agreed that one of the dimensions of leaders with integrity is "leaders deliver as what they promise" and some said, "I really trust my boss because he always say what he means"; "I have no doubt about her because she always keep her promises"; "I cannot take or accept empty promises and I'm annoyed if someone did not keep her promises"; "I always depend on him because by hook or other means, he would deliver whatever he promises."; "my employees believe me because I mean what I say" and "being a director myself, I always advise my managers to "walk the talk or otherwise they would lost all the credibility and the support from the management team as well as the employees".

Seventy-seven interviewees or 92.8 percent of the total number of interviewees voted that a leader with integrity is honest and sincere in action. They also give remarks such as "integrity encompasses honesty"; "do not backstab or speak badly of others". "Normally they are positive in their outlook and appreciate people for what they are. Here too, there is good talent management" and "when he did something wrong, he honestly and openly admit it".

Seventy-four interviewees or 89.2 percent of the total number of interviewees expressed that a leader with integrity is dependable and can be trusted and some said, "Integrity is being trusted, it's about trustworthiness"; "Integrity is about being able to trust the person; we can depend on the person (for help)"; "(s)he is responsible, and always do responsible acts". "(S)he who lives up to all his or her good name, subscribing to the good virtues and is indeed reliable to him(herself) and to others."; "an individual who is constantly honest and trustworthy even when nobody is around him or her"; "(s)he is a person who live by his or her beliefs/values/principles". And "when he promises you something, he would not change or shift a bit hence I am confident that he is reliable."

Sixty-nine interviewees or 83.1 percent of the total number of interviewees indicated that "Confucian leaders are of high integrity." Some mentioned that "They set good example."; "If I find out that something is fishy with the business dealing, I will retreat"; "I only deal with people of high integrity"; "I give full support and trust to honest people and I know that it takes time to trust a person"; "I am very careful about my attitude and behavior. I know that if I don't act properly my company's reputation would be at stake" and "I like to make friends with people of high integrity because I feel safe when I do business dealings with them".

Sixty-five interviewees or 78.3 percent of the total number of interviewees highlighted the importance of being ethical as a way of upright leaders. They pointed out that Holds high the value of humanity (rén 仁).”; "Confucian leaders are ethical."; "they would normally do things for humanity."; "I admire his leadership because he respects the dignity and the rights of others"; "I must say he is ethical because he always demonstrate a level of integrity to us that is important for stimulating a sense of leadership trustworthiness" and "we accept his vision because of his ethical beliefs, values and decisions."

Sixty interviewees or 72.2 percent of the total number of interviewees agreed that one of the dimensions of leaders with integrity is they have "no self-interest or personal gain" and some advised that "Does not engage in bad office politics; why bad office politics? These are actions that can harm others and the organization. These are actions that suit the individual as well as for the person's self-gain".

Table 2 shows some key responses verbalized by the interviewees.

Table 2. The interviewees' responses on the value of integrity, the Confucian perspective

\begin{tabular}{lcc}
\hline Responses & $\begin{array}{c}\text { Number of } \\
\text { Interviewees }\end{array}$ & $\begin{array}{c}\text { Percentage (\%) } \\
\text { of Interviewees }\end{array}$ \\
\hline $\begin{array}{l}\text { Delivering What Have Been Promised } \\
\text { "I can indeed trust my boss; he always say what he means"; "I am certain } \\
\text { about her because she always keep her promises"; "I cannot take or accept } \\
\text { empty promises and I'm annoyed if someone did not keep her promises"; "I }\end{array}$ & 95.1 \\
always depend on him because by hook or other means, he would deliver. & \\
He delivers whatever he promises."; "My employees believe me because I \\
mean what I say" and "being a director myself, I always advise my \\
managers to "walk the talk "or otherwise they would lost all the credibility \\
and the support from the management team as well as the employees". \\
\hline
\end{tabular}


Being Honest And Sincere In Actions

"Integrity includes honesty"; "a person of high integrity does not backstab or speak badly of others". "Usually, they're positive in their outlook and appreciate people for what they are. Then again, there is also good talent management." and integrity is "when a person did something wrong, (s)he honestly and openly admits it"

Being Dependable And Can Be Trusted

"Integrity is trustworthiness". "Integrity means being able to trust the person"; "we can depend on the person for help"; "(s)he is responsible, and always do responsible acts."; " (S)he who lives up to all the good virtues and is reliable to him(herself) and to others."; "An individual who is constantly honest and trustworthy even when nobody is around him or her"; "the person is someone who lives by his or her beliefs/values and principles" and "when he promise you something, he would not change/shift a bit hence he is reliable."

\section{Being of High Integrity (廉, lian)}

"Confucian leaders are of high integrity"; "they set good example." "If I find out that something is fishy about the business dealing, I will retreat"; "I prefer dealing with people of high integrity"; "I give full support and trust to honest person(s) and I know that it takes time to trust a person"; "I am very careful about my attitude and behaviour. I know that If I don't act properly my company's reputation would be at stake" and "I like to make friends with people of high integrity because I feel safe when I do business with them".

\section{Being Ethical}

"Being ethical is synonymous with integrity"; such a leader "holds high the value of humanity (rén, 仁).”; "Confucian leaders are ethical."; "they would normally do things for humanity."; "I admire his leadership because he respects the dignity and the rights of others."; "I must say he is ethical because he always demonstrate a level of integrity to us that is important for stimulating a sense of trustworthiness." and "we accept his vision because of his ethical beliefs, values and decisions." And "keep on improving oneself" and that "in itself is to be appreciated and has an intrinsic value".

\section{No Self- Interest Or Personal Gain}

"Such a person does not engage in bad office politics; why bad office politics? These are actions that can harm others and the organization. These are actions that suit the individual as well as for the person's self-gain or interest" and "Such a corporate person will also promote corporate social responsibility such as helping out the community in which the company is functioning."

\section{Analysis and Discussions}

\subsection{Being in Alignment with the Dao}

- Enjoys the Clarity And Peace of Mind (Of Clear Conscience)

- Pursues the Right Actions

- Feels In Abundance

Tao means "the way of life" and for Confucius, the attainment of Tao is the ultimate enlightenment in one's life. Low (2011: 118) has pointed out that Confucianism stresses on attaining Dao in human living; the writings of Confucius deal primarily with individual morality and ethics (also see Low, 2008 - Confucian ethics and business responsibility to the various stakeholders), and the proper exercise of political power by the rulers or leaders.

The upright person operates or works in alignment with the Dao. (S)he acts naturally. In fact, there is no anomic feelings or any sense of guilt or dissatisfaction when (s)he does things. (S)he feels very much in abundance; 
there is a feeling of affluence. More importantly, there is congruency between a person's values and key beliefs and his actions and deeds. There is, overall, clarity and peace of mind and the pursuit of right actions. Here, the authors can cite spiritual leaders and again the Dalai Lama comes to mind; he once "said..., 'I don't dislike the Chinese, only their actions.' To me, the most mystical thing about him is also the most ordinary: the Dalai Lama is happy. He's happy in the midst of chaos and turmoil. The most inspiring thing he ever told me was to ignore all organized faiths and keep to the road of higher consciousness" (Chopra, 2008: 29).

\subsection{Being of High Integrity (廉, lian)}

- Delivers What Have Been Promised

- Is Honest (真誠, zhēn chéng)And Sincere (誠實, chéng shí) (Embraces the Purity of Heart)

- Is Reliable And Can Be Trusted

Ordinarily, when one is of high integrity, one would deliver what one has promised; there is action and results. Confucius pointed out, "How can one be acceptable without being trustworthy in words? This is just like a cart without a collar-bar or a carriage without a yoke-bar. How can it move forward?" (Analects of Confucius, II: 22).

Indeed, integrity encompasses honesty and trustworthiness, one can be depended upon; others or the followers can depend on or trust the person.

Integrity is authentic leadership, the leader stands for what he is. It is the opposite or antithesis of hypocrisy. Integrity refers to behavior that is honest, sincere and ethical (there is purity of heart), making a person trustworthy. Honesty refers to trustworthiness rather than falsehood, trickery or deception. Integrity is the most important asset that one can possess. (Lussier and Achua, 2007: 34). After all, people with Confucian value of integrity consciously uphold their values and are fired up by such unshakeable convictions that they honorably live as well as die by them. And integrity also becomes one of the pillars of their leadership style and ways.

\subsection{Being Ethical (倫 理, lún lǐ) And Humane (rén, 仁)}

- Holds High the Value of Humanity (rén, 仁)

- Keeps On Improving Oneself

- Is Socially Responsible (Cares for the Community)

It is noteworthy that one of the key moral principles for a jun zi (君子) to abide by is loyalty, not necessarily to the sovereign or ruler, but to the lifelong mission of practicing the Way of Humanity. The Master himself was known not for his loyalty to any ruler, but for his loyal commitment to preaching the Way of Humanity (other names include: "benevolence", "human-heartedness") (Sun, 2008: 7, 10). The Confucian leader holds high the value of humanity (rén, 仁); "Confucian leaders are ethical"; "being ethical is synonymous with integrity". "They would normally do things for humanity." Sixty-five interviewees or 78.3 percent highlighted that interestingly, the Confucian value and practice of integrity means that the leaders "keep on improving oneself" and that "in itself is to be (better) appreciated and has an intrinsic value", it reflects the Confucian value of learning and continuous improvement, and the movement towards (the attainment of the) Dao.

Indeed leaders must be ethical and this is in line with being of high integrity. And interestingly, this aptly fit with Lussier and Achua's (2007: 34) observations that integrity is the most important asset that one can possess.

We can also take it that such a corporate person with integrity, filled with loving-kindness, "will also promote corporate social responsibility such as helping out the community in which the company is functioning" (one interviewee's input). Here, we would cite the People's Republic of China, Hu Jin Tao, as an example. Though he was the first Chinese leader who grew up in the aftermath of the revolution that established communism in 1949, $\mathrm{Hu}$, to the authors, can be said to be essentially 'Confucian'. One can argue that traces of Confucianism are still around when $\mathrm{Hu}$ "has proclaimed the goal of a harmonious society whose components work together by consensus rather than direction. It is a principle he has tried to apply to international affairs as well" (Kissinger, 2008: 33).

\subsection{Being a Role Model}

- Sets the Example

- Is Courageous to Set the Example

- Has the Mental and Moral Strengths

For Confucius, "without integrity and good examples, a leader becomes "a person who lacks gravity (and) does not inspire respect" (Confucius cited in Chew, 2000: 2, italics ours). A leader gains moral grounds and attracts 
his followers as a role model of good examples. His or her actions are louder than words. As highlighted by Low (2006), role models should be assessed in the light of honesty and integrity. When it comes with the time that the followers have doubt and question their leaders' honesty and integrity, leaders cannot be role models. In business, a caring leader is courageous, honest and has a real sense of commitment to honesty and transparency. One has the mental and moral strengths to venture, persevere and withstand difficulties. In this study, sixty-nine interviewees or 83.1 percent of the total number of interviewees indicated that caring leaders, the Confucian way "are of high integrity". "Upright", "they set good examples" and they "cannot accept empty promises and their people know me best". "If I find out that something is fishy with the business dealing, I will retreat"; "I only deal with people of high integrity"; "I give full support and trust to honest people and I know that it takes time to trust a person". "I am very careful about my attitude and behavior. I know that if I don't act properly my company's reputation would be at stake" and "I like to make friends with people of high integrity because I feel safe when I do business with them".

Examples here are many, and include the late Japanese corporate leader Matsushita Konosuke, Aung San Suu-Kyi (Myanmar's Nelson Mandela, Suu-Kyi is a courageous advocate for human rights and democracy, and she was the world's only imprisoned Nobel Peace Prize recipient at that time) and Mahatma Gandhi (who upheld the value of integrity through example setting and non-violence).

\subsection{Being Professional (In Accordance to the Rectifications of Names)}

- Is Consistent and Steadfast (Honest)

- Is Detached (No Self- Interest or Personal Gain)

- Is Self-disciplined (自律, Zì lù)

This is applicable and relevant to the Confucian leader in terms of being a corporate person. A corporate person, more so, a corporate leader has to be professional. And being ethical is also about being professional; and to be professional is to be consistent. "You have to be yourself" (Yu Dan, 2009: 26). Integrity cannot really be situational, changing to suit the situation; one should not be chameleon-like; one's honor, uprightness and dignity should prevail at all times. If one is inconsistent, one is unreliable. And one is clumsy and unprofessional. Besides, one cannot compartmentalize one's office life from personal life and so on.

Confucius highlighted that, "Before praising a man who is honest in speech, one should observe: Is he a true gentleman or is his dignity just pretense?" (Analects of Confucius, XI: 21). "Upright" (several interviewees' input), one should not be involved in gossips and rumors. Being of high integrity and professional is also about being honest and sincere in actions and one can be depended upon at all times. True, this may sound as strict but it is also a matter of self-discipline and self-discipline, so to speak, grows one's integrity.

Here, it is noteworthy that being professional, the Confucian leader would not engage in bad office politics. "Such a person does not engage in bad office politics; why bad office politics? These are actions that can harm others and the organization. These are actions that suit the individual as well as for the person's self-gain or interest". In other words, the person is not greedy, let alone self-interested. Responses from the interviewees include the fact that "integrity (also) includes honesty"; "a person of high integrity does not backstab or speak badly of others". "Usually, they're positive in their outlook and appreciate people for what they are". And all these can be surmised as being ethical, detached and of high integrity as well as being professional.

Integrity also encompasses professionalism, and it reflects the person's title, what (s)he is doing or what (s)he stands for. Take for example, when one is a teacher; (s)he is addressed as teacher (老師, “laoshi") followed by his or her last name. This can be interpreted in the light of the Confucian Rectification of Names. Proper titles and names should be attributed or assigned to people and things; proper or right names are given to everything. A ruler is a ruler and a leader is a leader.

Figure 1 summarizes the key characteristics of leaders/managers who embrace and practice the value of integrity. 


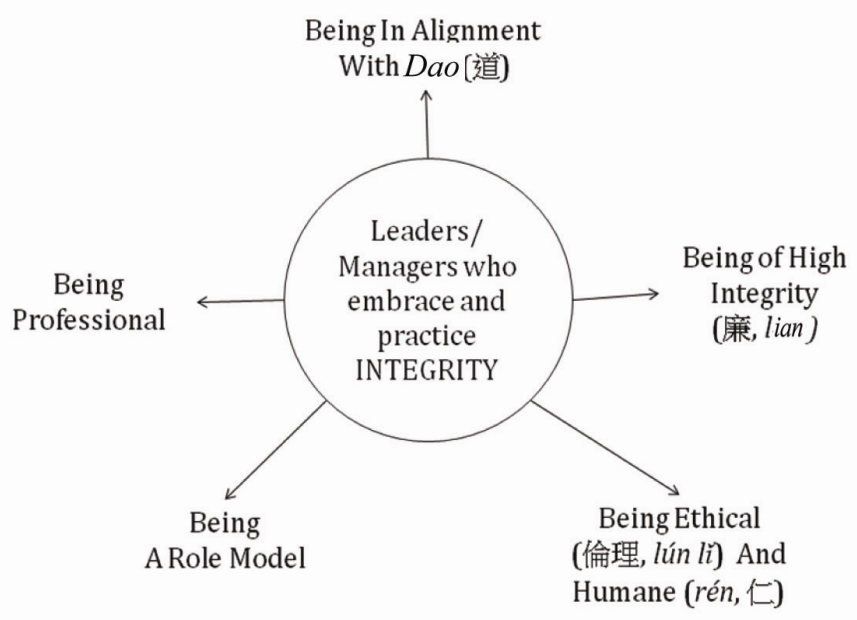

Figure 1. Key characteristics of leaders/managers who embrace and practice the value of integrity

Table 3 summarizes the characteristics of leaders/managers who practice the value of integrity.

Table 3. Characteristics of Confucian leaders/managers practicing the value of integrity

\begin{tabular}{|c|c|c|}
\hline \multicolumn{3}{|c|}{ Characteristics Of Confucian Leaders/Managers Practicing The Value of Integrity } \\
\hline \multirow{11}{*}{$\begin{array}{l}\text { Leaders/Managers } \\
\text { who are: }\end{array}$} & Being In Alignment With The Tao & $\begin{array}{l}\text { - Enjoys the Clarity And Peace of Mind } \\
\text { (Of Clear Conscience) }\end{array}$ \\
\hline & & - Pursues the Right Actions \\
\hline & & - Feels In Abundance \\
\hline & Being of High Integrity (廉, lian) & - Delivers What Have Been Promised \\
\hline & $\begin{array}{l}\text { Being Ethical (倫 理, lún lì) And } \\
\text { Humane (rén, 仁) }\end{array}$ & $\begin{array}{l}\text { - Is Honest (真 誠, zhēn chéng) And } \\
\text { Sincere (誠 實, chéng shí) (Embraces the } \\
\text { Purity of Heart) }\end{array}$ \\
\hline & & - Is Reliable And Can Be Trusted \\
\hline & Being A Role Model & - Sets the Example \\
\hline & & - Is Courageous to Set the Example \\
\hline & & - Has the Mental And Moral Strengths \\
\hline & $\begin{array}{l}\text { Being Professional (In Accordance } \\
\text { to the Rectifications of Names) }\end{array}$ & $\begin{array}{l}\text { - Is Consistent And Steadfast (Honest) } \\
\text { - Is Detached (No Self- Interest Or } \\
\text { Personal Gain) }\end{array}$ \\
\hline & & - Is Self-disciplined (自 律, Zì lì) \\
\hline
\end{tabular}

\section{Limitations and Benefits of the Study}

One of the key limitations of the study is that it focuses on selected respondents' interview outcome only. Nonetheless, based on the study's findings, it can be seen that being human-orientated (practicing rén, 仁), encouraging continuous learning, listening (being humble); being of high integrity (廉, lian) and applying reciprocity (恕, shù ) are important leadership behaviors; and they can make the Confucian leader appealing or influential, and these behaviors are also very motivating to the employees. Interestingly, from this study, the Confucian idea or concept of professionalism is also interpreted and derived, laying the foundations for further studies.

This study was conducted in Chinese-minority Brunei and in terms of the future research directions, it is hoped 
that further studies can also be made on how leaders with integrity behave in other South East Asian countries be it with Chinese minority or majority.

\section{Concluding Remarks}

The teachings of Confucius stresses on [the Dao; overall seen as less emphasized or underscored and on the practical side,] correct moral and ethical behavior of both the individual as well as the family/organization/nation. When the leader can change one and others around him, (s)he can change or influence others to change, more people would change until ultimately, the society would also change.

His teachings underscore the importance of social relationships, justice and sincerity. Overall, they are aimed at creating peace and harmony in a society with social responsibility. Having and cultivating a leader with integrity is to enable the leader to set excellent examples for the followers and others, leading and encouraging people to conduct a proper life and livelihood and having good relationships with the people around oneself. And in doing so, more people would attain similar good virtues; and if this continues, there would be fewer conflicts in relationships and this creates positive energies in teamwork and group dynamic harmony. And all would then be working towards a peaceful, harmonious society, and since everybody behaves in a socially responsible way, the people in business, when relating with their stakeholders (community and society) would be able to prosper in their businesses. Besides, there would be fewer problems in business dealings and transactions in the wider society and country, and overall the wider society and country could also prosper.

\section{References}

Ang, S. L., \& Low, K. C. P. (2012). The Chinese and Their Motivation-The Brunei Case Study. Journal of Research in International Business Management, 2(2), 039-050.

Cavana, R. Y., Delahaye, B. L., \& Sekaran, U. (2001). Applied business research, qualitative and quantitative methods. Australia: John Wiley and Sons.

Chai, S. C., Lai, P., \& Sia, Y. H. (1994). Analects of Confucius. Sinolingua, Beijng, China.

Chew, K. H., P. (2000). A gentleman's code. Singapore: Graham Brash (Pte) Ltd.

Chopra, D. (2008). The Time 100 Most Influential Individuals. The Time, p. 29.

De Bary, W. T., Chan, W. T., \& Watson, B. (1960). The sources of Chinese tradition. Columbia University Press.

Gill, J., \& Johnson, P. (1997). Research methods for managers (2nd ed.). London: Paul Chapman Publishing Ltd.

Haworth, J. (1996). Psychological research: Innovative methods and strategies. Great Britain: Routledge. http://dx.doi.org/10.4324/9780203294314

Kothari, V. B. (2010). Executive Greed. New York, USA: Palgrave Macmillan. $\mathrm{http}: / / \mathrm{dx}$.doi.org/10.1057/9780230109650

Lien, Y. C., \& Kraar, L. (1994). From Chinese villager to Singapore tycoon: My life story. Singapore: Times Publishing International.

Low, K. C. P. (2002). Corporate Culture and Values: Perception of corporate leaders of co-operatives in Singapore. Ph.D. Thesis, the University of South Australia, Adelaide.

Low, K. C. P. (2006). Motivation, the Chinese leadership way in Singapore's small and medium companies. The Icfaian Journal of organizational behavior, V(1), 80-90. The Institute of Chartered Financial Analyst India: ICFAI University Press.

Low, K. C. P. (2006a). Father leadership - The Singapore case study. Management Decision, 44(2), 89-104. http://dx.doi.org/10.1108/00251740610641481

Low, K. C. P. (2008). Confucian ethics \& social responsibility - The golden rule \& responsibility to the stakeholders. Ethics \& critical thinking Journal, 2008(4), 46-54.

Low, K. C. P. (2009). How to lead in today's context? What leadership skills set do we need? Leadership \& organizational management Journal, 2009(1), 48-56.

Low, K. C. P. (2010). Values make a leader, the Confucian perspective. Insights to a changing world Journal, 2010(2), 13-28.

Low, K. C. P. (2010a). Applying strategic leadership, the Way of the Dragon. e-Leader CASA: Chinese American Scholars' Association Conference, Singapore. 
Low, K. C. P. (2011). Confucianism versus Taoism. Conflict resolution \& negotiation Journal, 2011(4), 111-127.

Low, K. C. P., \& Ang, S. L. (2011). Confucian ethics and the stakeholder theory in business. i-manager's Journal on Management, 5(4), 8-20.

Low, K. C. P., \& Ang, S. L. (2011a). How to be a good teacher? Educational Research, 2(5), 1118-1123.

Low, K. C. P., \& Ang, S. L. (2011b). Information Communication Technology (ICT) for Negotiations. Journal of Research in International Business and Management, 1(6), 183-196.

Low, K. C. P., \& Ang, S. L. (2011c). Lessons on positive thinking and leadership from Confucius. Global Science and Technology Forum (GSTF) Business Review, 1(2), 199-206.

Low, K. C. P., \& Ang, S. L. (2011d). Confucius, Confucian Values and their Applications on Marketing-The Brunei Perspective. Journal of Research in International Business Management, 1(9), 293-303.

Lussier, R. N., \& Achua, C. F. (2007). Effective Leadership. Thomson South Western, USA: International Student Edition.

Roscoe, J. R. (1975). Fundamental Research Statistic for the Behavioural Sciences (2nd Ed.). New York: Holt, Rinehart and Winston.

Sekaran, U. (2000). Research Methods for Business. John Wiley \& Sons, Inc.

SEP. (2011). Stanford Encyclopaedia of Philosophy. Retrieved from http://plato.stanford.edu/entries/integrity/

Sun, C. T. L. (2008). Themes in Chinese Psychology. Singapore: Cengage Learning Asia Pte. Ltd.

Wang, G. (2004). Confucianism. In F-J Richter \& P. C.M. Mar (eds.), Asia's New Crisis: Renewal through total ethical management (PP. 51-62). Singapore: John Wiley \& Sons (Asia).

Wilson, J. R. (2008). 151 quick ideas to inspire your staff. Malaysia: Advantage Quest Sdn. Bhd.

Yu Dan. (2010). Confucius from the heart. London: Pan Books.

Zhou, K. (2005). A Basic Confucius. USA: Long River Press. 